[Regular Paper]

\title{
Characterization of Carbonaceous Compounds Deposited on NiMo Catalyst Used for Ultra Deep Hydrodesulfurization of Gas Oil by Means of Temperature-programmed Oxidation Method
}

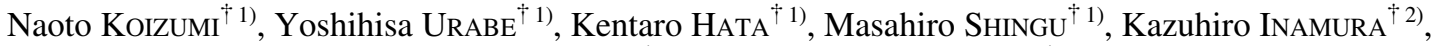 \\ Yoshikazu Sugimoto ${ }^{\dagger 3}$, and Muneyoshi Yamada ${ }^{\dagger 1) *}$ \\ ${ }^{\dagger 1}$ Dept. of Applied Chemistry, Graduate School of Engineering, Tohoku University, Aoba 6-6-07, Aramaki, Aoba-ku, Sendai 980-8579, JAPAN \\ ${ }^{\dagger 2}$ Central Research Laboratories, Idemitsu Kosan Co., Ltd., 1280 Kami-izumi, Sodegaura, Chiba 299-0293, JAPAN \\ $\dagger 3)$ Advanced Fuel Group, Energy Technology Research Institute, National Institute of Advanced Industrial Science and Technology, \\ 1-1-1 Higashi, Tsukuba, Ibaraki 305-8565, JAPAN
}

(Received September 3, 2004)

\begin{abstract}
Ultra deep hydrodesulfurization (HDS) of several types of gas oil were performed over NiMo catalyst under various conditions and the carbonaceous deposits on the spent catalysts were characterized by temperature programmed oxidation (TPO). $\mathrm{CH}_{3} \mathrm{CN}$ was formed in addition to $\mathrm{H}_{2} \mathrm{O}, \mathrm{CO}, \mathrm{CO}_{2}$ and $\mathrm{SO}_{2}$ by TPO, indicating that the carbonaceous compounds deposited on the spent catalysts contain nitrogen atoms. Curve fitting analyses showed that both $\mathrm{CO}_{x}$ and $\mathrm{CH}_{3} \mathrm{CN}$ profiles could be deconvolved into two or three Gauss-Lorentz type peaks. Two peaks always appeared below $680 \mathrm{~K}$ whereas another peak was observed in the range from $680-690 \mathrm{~K}$ if ultra deep HDS was performed above $580 \mathrm{~K}$. These results indicated that at least two or three types of carbonaceous compounds with different combustion properties are deposited on the spent catalysts depending on the reaction conditions. No clear correlation was found between the amounts of carbon and nitrogen atoms contained in the carbonaceous compounds combusted below $680 \mathrm{~K}$ and the reaction conditions or the feed compositions such as a total nitrogen content and $90 \%$ distillation temperature, $T_{90}$. On the other hand, the amounts of carbon and nitrogen atoms included in the refractory carbonaceous compounds increased with both higher $T_{90}$ and reaction temperature. Therefore, the carbon and nitrogen atoms included in the refractory carbonaceous compounds originate from the adsorption of heavy molecule(s) containing nitrogen atom(s) in the feed. At higher reaction temperatures, polymerization of the adsorbed species was facilitated, resulting in larger amounts of the refractory carbonaceous compounds. Larger amounts of refractory carbonaceous compounds were associated with lower residual HDS activity, suggesting that the deposition of such compounds is one of the reasons for the catalyst deactivation.
\end{abstract}

\section{Keywords}

Ultra deep hydrodesulfurization, Catalyst deactivation, Carbonaceous deposit,

Temperature-programmed oxidation

\section{1. 緒言}

軽油中の硫黄分を 10 massppm以下（単体硫黄換算）に低減 する軽油の超深度脱硫反応は，ディーゼル車の低排出化におい て最も重要な技術課題の一つである。これまでに難脱硫性の 4,6-ジメチルジベンゾチオフェンをターゲットとした高活性触 媒の開発が試みられてきており, 既に超深度脱硫を達成できる 触媒が開発されつつある ${ }^{1,2)}$ 。しかし, 従来の深度脱硫反応で は触媒の劣化はほとんど問題とならなかったのに対して, 超深 度脱硫反応では特にNiMo系触媒を用いた場合に通油の初期に 扮ける劣化速度が大きいと報告されている ${ }^{1,2)}$ 。超深度脱硫反

* To whom correspondence should be addressed.

* E-mail: yamada@erec.che.tohoku.ac.jp
応は深度脱硫反応と比較して反応開始温度がやや高い, 言い換 えれば運転可能な温度域が相対的に狭いため, 触媒の劣化対策 はプロセスの実用化に扔いて極めて重要な意味を持つ。特に, 触媒の改良によって劣化を緩和できれば経済性にも大きなイン パクトを与えると期待されるが, そのためには超深度脱硫触媒 の劣化機構の解明が不可欠である。

軽油の深度脱硫反応と対照的に, 石炭液化油, 残油の水素化 精製等に强いては触媒の劣化が著しく, 劣化対策がプロセスそ のものという場合も少なくない3)。これまでの多くの研究から， 通油初期の急激な劣化はコーキング（炭素質化合物のたい積） に, 中・後期にかけての劣化はメタル分のたい積によると考元 られている33,44。軽油はメタル分をほとんど含まないため, 超 深度脱硫触媒の劣化には炭素質化合物のたい積が大きな影響を 及ほすをと予想される。そのため, 本研究は超深度脱硫反応に使 
Table 1 Composition of the Feed and Reaction Conditions Employed for Ultra Deep HDS of Gas Oils

\begin{tabular}{|c|c|c|c|c|c|c|}
\hline \multirow{2}{*}{ Notation $^{\text {a) }}$} & \multicolumn{3}{|c|}{ Composition of the feed } & \multicolumn{3}{|c|}{ Reaction conditions } \\
\hline & $\mathrm{S}$ content [massppm-S] & $\mathrm{N}$ content [massppm-N] & $T_{90}^{\mathrm{b})}[\mathrm{K}]$ & $T_{\max }^{\mathrm{c})}[\mathrm{K}]$ & $\operatorname{LHSV}\left[\mathrm{h}^{-1}\right]$ & Days on stream \\
\hline Spent（i） & 11600 & 100 & 622 & 583 & 1.5 & 2 \\
\hline Spent（ii） & 12200 & 89 & 627 & 633 & $1.0-2.0$ & 15 \\
\hline Spent（iii） & 13300 & 110 & 636 & 618 & $1.5-2.0$ & 150 \\
\hline Spent（iv） & 12000 & 120 & 638 & 643 & $1.5-2.1$ & 72 \\
\hline Spent（v) & 12000 & 120 & 638 & 663 & $1.0-3.0$ & 84 \\
\hline Spent（vi） & 12000 & 120 & 638 & 657 & $1.5-2.1$ & 172 \\
\hline
\end{tabular}

a) Spent (iv)-(vi) were subjected to accelerated deterioration testing (see text).

b) $90 \%$ distillation temperature.

c) Maximum reaction temperature.

用した NiMo触媒上の炭素質化合物の性状とたい積量，さらに は触媒の劣化との関係を明らかにすることを目的とした。

重質油や残油の水素化精製触媒に関しては，炭素質化合物の 構造やたい積量と触媒の劣化との相関を検討するため, 昇温酸 化 (TPO) 法 ${ }^{5) ~ 11), ~}{ }^{13} \mathrm{C}-\mathrm{NMR}$ (nuclear magnetic resonance) ${ }^{9), 12) \sim 15)}$, XPS (X-ray photoelectron spectroscopy $)^{13), 16) ~ 18) ， あ る い は R a m a n ~}$ 分光法 ${ }^{18)}$ 19) 等の手法によりたい積炭素質化合物のキャラク夕 リゼーションが行われてきた。これらの手法の中でTPOは特 にたい積物の定量に優れている。また，TPOを用いれば触媒 上に反応性（燃焼性状）の異なる炭素質化合物がたい積してい る場合にそれを区別できる可能性がある。たとえば，Marafi $ら^{10)}$ は, 減圧軽油の水素化脱硫 (HDS) に使用した $\mathrm{NiMo} / \mathrm{Al}_{2} \mathrm{O}_{3}$ を $\mathrm{TPO}$ に供すると $\mathrm{CO}, \mathrm{CO}_{2}$ の MS プロファイルにブロードな 2 本のピークが現れることを見出し，使用済触媒上に燃焼性状の 異なる炭素種がたい積していると推定した。類似のプロファイ

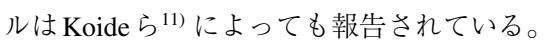

さらに, 使用済触媒の TPOではこれまでに $\mathrm{H}_{2} \mathrm{O}, \mathrm{CO}, \mathrm{CO}_{2}$, $\mathrm{SO}_{2}$ に加えて $\mathrm{NO}^{7,9)}$ (11) $\mathrm{NO}_{2}{ }^{10), 11)}$ が生成することが見出され ている。つまり，TPOによりたい積炭素質化合物に含まれる 炭素種だけでなく窒素種の反応性に関する知見も得ることがで きる。たい積炭素質化合物の原因物質は原料油中の窒素を含む 多環芳香族化合物と推定されているため ${ }^{20)}$, たい積窒素種の情 報を得ることは炭素質化合物の由来を検討する上で重要であ る。Zauthen ら ${ }^{9)} は, \mathrm{NO}$ のS プロファイルに2本のピークが 現れること, 高温側のピークは $\mathrm{CO}_{x}$ のものよりやや高温側に現 れることを見出した。このことから, 使用済触媒上には燃焼性 状の異なる少なくとも2 種類の窒素種がたい積しており, 高温 側で燃焼する窒素種は触媒上に強く吸着し，その上を炭素リッ チなたい積物が覆うと提案した。 $\mathrm{NO}_{x}$ のピークが $\mathrm{CO}_{x}$ のものよ り高温側に現れる現象は他の研究者によっても見出されてい る ${ }^{10), 11)}$ 。これらの結果は, 触媒上に炭素種と窒素種が不均一に たい積している可能性があることを示している。

このように，TPOを用いることによって炭素質化合物の燃 焼性状や構造に関して有用な知見を得ることができるが, 従来 の TPOを用いた研究では定性的な検討が多く, 定量性に重点 をおいた研究は少ない8)。特に, 燃焼性状の異なる炭素種や窒 素種がどの程度たい積しているのかはこれまでに調べられてい ない。Terman $ら^{21)}$ は，ビチューメンの HDS 反応に使用した $\mathrm{CoMo} / \mathrm{Al}_{2} \mathrm{O}_{3}$ 上に反応䨌囲気で除去される炭素質化合物と除去 されない反応性の低い炭素質化合物がたい積しており, 後者の
炭素質化合物が触媒の劣化を引き起こすと推定した。このこと を考慮すると, 個々の炭素種や窒素種のたい積量と触媒の残存 活性との関係を明らかにすることにより劣化の原因物質を特定 できる可能性がある。

以上の点を考慮して, 本研究ではNiMo触媒を用いて数種の 軽油の超深度脱硫反応を種々の条件で行い, 反応後の触媒上に たい積した炭素質化合物の性状やたい積量を TPOによりキャ ラクタライズした。TPO プロファイルを詳細に解析すること により, 使用済触媒上の炭素質化合物の燃焼性状やたい積量を 明らかにし, 軽油の組成や反応条件, さらには触媒の残存活性 との相関を調べた。これらの結果に基づき, 炭素質化合物の生 成機構や触媒の劣化に対する影響を検討した。

\section{2. 実験}

\section{1. 軽油の超深度脱硫反応}

本研究では, 固定床流通式反応装置にて, 組成の異なる軽油 の超深度脱硫反応を同一の $\mathrm{Al}_{2} \mathrm{O}_{3}$ 担持 $\mathrm{NiMo}$ 系触媒 ( $\mathrm{PEC}$ 袖ヶ 浦第一研究室開発, $\mathrm{NiO}: 6$ mass \%, $\mathrm{MoO}_{3}: 32$ mass\% $)^{1)}$ を用い て以下の 2 通りの方法で行い, 計 6 種類の使用済触媒を得た。

(i) 予備硫化後, 生成油の硫黄濃度が 50 massppm（単体硫黄 換算, 以下同じ）となるように反応温度を設定しながら 軽油を 15 ないし 150 日間流通した。また, 予備硫化直後 の触媒上にたい積した炭素質化合物に関する知見を得る ため, 予備硫化後に $583 \mathrm{~K} て ゙ 2$ 日間だけ軽油を流通した ものも調製した ${ }^{2)}$ 。

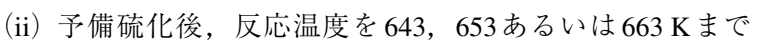
上げてその温度を所定の期間保持した後, 生成油の硫 黄濃度が 10 massppm となるように反応温度を設定しな がら軽油を流通した ${ }^{22)}$ 。

（ii）は高温の反応需囲気下で触媒を強制的に劣化させてか ら HDS 活性を調べたもので, 本論文では便宜上（i）を実劣化 試験，（ii）を加速劣化試験と呼ぶ。なお，いずれの場合も $\mathrm{H}_{2}$ 圧を5.0 MPa とした。各使用済触媒の表記法と履歴を Table 1 に示す。なお, Spent（ii）を用いた超深度脱硫反応では反応温 度の影響を調べるために, 生成油の硫黄濃度と無関係に短期間

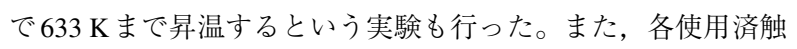
媒の充填位置に関しては, Spent（i）～Spent（iv）が上流，中間， 下流に充填されていたものの混合物であり, Spent $(\mathrm{v})$ と Spent（vi）は反応器の中間に充填されていたものである。反 応器から取り出した使用済触媒は全て軽油あるいはトルエン中 
で保管した。

\section{2. 使用済触媒の前処理方法}

使用済触媒の TPO プロファイルを測定する前に，以下の前 処理を施した。まず，ソックスレー抽出装置を用いトルエンを 溶媒として使用済触媒を洗浄した。約 12 時間ごとにトルエン を交換し, トルエンの着色が見られなくなるまで洗浄を繰り返 した。次いで, 洗浄した使用済触媒をエバポレーターを用いて $333 \mathrm{~K}$ で 2 時間乾燥させ, さらに電気炉にて $393 \mathrm{~K}$ で 12 時間乾 燥させた。なお，次節で述べるように，TPO測定の前に He処 理を施す場合には，エバポレーターおよび電気炉による乾燥の みを施した触媒を使用した。いずれの場合も，電気炉による乾 燥後のものを $60 \sim 100$ メッシュに整粒し，空気中で保管した。

\subsection{TPO測定}

使用済触媒の TPO プロファイルの測定にはオンライン GC (gas chromatograph, 島津製作所製, GC-2010あるいはGC14B) およびオンライン GC/MS ( GC/mass spectroscopy，島津製作所 製，QP 5000）を備えた固定床流通式反応装置を使用した。前 項で述べた触媒を再度電気炉にて約 12 時間乾燥させ，それを 所定量ひょう量して石英製の反応器 (内径 $4 \mathrm{~mm}$ ) に充填し, 反応装置に取り付けた。

オンライン GC/MS を用いる場合には約 $0.2 \mathrm{~g}$ の使用済触媒を 反応器に充填し, まず He（純度> $99.99995 \%$ ）気流を用い,

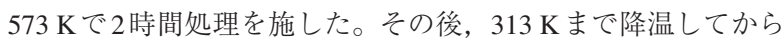
$\mathrm{He}$ 気流を $10 \% \mathrm{O}_{2} / \mathrm{He}$ (純度>99.99995％）気流に切り替え， 所定の時間経過してから $1023 \mathrm{~K}$ まて $5 \mathrm{~K} \cdot \mathrm{min}^{-1} て ゙$ 昇温した。 $1023 \mathrm{~K}$ に達した後，その温度をさらに1時間保持した。GC/MS の測定開始質量数と測定終了質量数をそれぞれ 10 と 200 とし, 走査速度を $250 \mathrm{amu} \cdot \mathrm{s}^{-1}$ とした。

オンライン GCを用いる場合には約 $0.05 \mathrm{~g}$ の触媒を反応器に 充填し, 触媒層の温度を $313 \mathrm{~K}$ に保持したまま，まず $10 \%$ $\mathrm{O}_{2} / \mathrm{He}$ (純度> $99.99995 \%$ ）気流を流通した。所定の時間経過 してから GC/MS を用いた時と同様に昇温した。なお，一部の 測定では $10 \% \mathrm{O}_{2} / \mathrm{He}$ 気流を流通する前に上記した $\mathrm{He}$ 処理を施 した。オンライン GCには GC/TCD (thermal conductivity detector) あるいは3 種類の検出器 (FID, フレームサーミオニック検出 器 (FTD), フレームフォトメトリック検出器 (FPD) ) を備え た GCを使用した。後者の GCは反応器からの流出ガスを三つ に分岐して各検出器に導入できるように改造したものである。 さらに，分岐点から FID (hydrogen-flame ionization detector) に 至る流路にメタナイザーを挿入する場合と挿入しない場合を選 択できるように改良した。

\section{3. 結果と考察}

\subsection{TPO 時の脱離生成物の検討}

\subsubsection{GC/MSによる脱離生成物の同定}

これまでに重質油の水素化精製に用いた触媒の TPOでは $\mathrm{H}_{2} \mathrm{O}, \mathrm{CO}, \mathrm{CO}_{2}, \mathrm{SO}_{2}$ に加えて $\mathrm{NO}^{7,9) \sim 11)}$ や $\mathrm{NO}_{2}{ }^{10,11)}$ が生成す ると報告されている。そこでこれらの研究を参考に，まず軽油 の超深度脱硫反応に使用した触媒を TPOに供した時の脱離生 成物を GC/MS を用いて同定した。

Spent（i）（iii）の TPO時に観察された主な質量数は $\mathrm{m} / \mathrm{z}=$ $32\left(\mathrm{O}_{2}\right)$ を除くと, $m / z=18, m / z=28, m / z=44$ および $m / z=64$
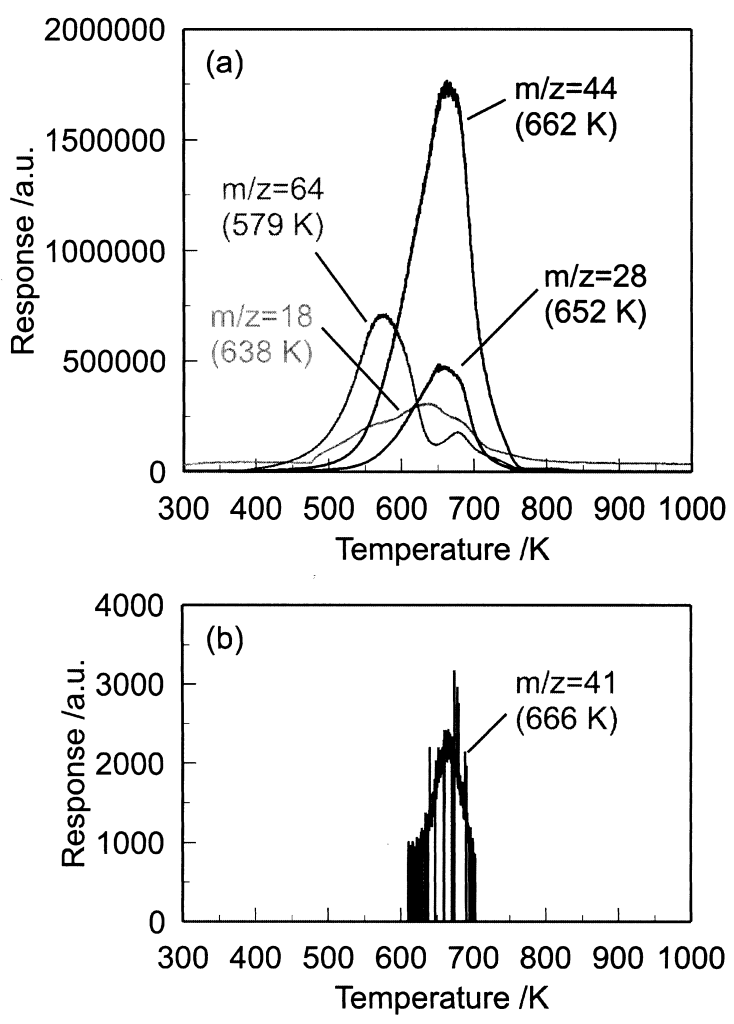

Numbers in parentheses indicate the peak top temperatures for each profile.

Fig. 1 Intensity Profiles for Selected Mass Numbers during TPO of the Spent Catalyst (Spent (iii), (a) $m / z=18,28$, 44 and 64 , (b) $m / z=41$ )

であった。これらの質量数は $\mathrm{TPO}$ 時に $\mathrm{H}_{2} \mathrm{O}, \mathrm{CO}, \mathrm{CO}_{2}$ 抢よび $\mathrm{SO}_{2}$ が生成することを示している。フレッシュ触媒を $5 \%$ $\mathrm{H}_{2} \mathrm{~S} / \mathrm{H}_{2}$ 気流を用いて硫化したものをin-situでTPOに供した場合 には, $m / z=64$ のほかに非常に強度の弱い $m / z=18$ が観察され ただけであった。このことから, 使用済触媒の TPO時に生成 する $\mathrm{CO}_{x}$ と大部分の $\mathrm{H}_{2} \mathrm{O}$ は使用済触媒上のたい積物に由来す る。Spent（iii）をTPOに供した時の各質量数の強度を温度の 関数として表したものを Fig. 1(a) に示す。 $m / z=18$ のプロファ イルは広い温度域で $\mathrm{CO}_{x}$ のものと重なっており, この触媒には 水素を含む炭素質化合物がたい積していることが示唆される。

また, いずれの使用済触媒の TPO 時にも $\mathrm{m} / \mathrm{z}=30$ や $\mathrm{m} / \mathrm{z}=46$ の質量数も観察された。これらの質量数から $\mathrm{TPO}$ 時に $\mathrm{NO}$ $\mathrm{NO}_{2}$ が生成する可能性があるが, $\mathrm{m} / \mathrm{z}=30$ と $\mathrm{m} / \mathrm{z}=46$ は $\mathrm{CO}_{2}$ のフ ラグメントでもあることに留意する必要がある。実際, これら の質量数のプロファイルはいずれも非常に強度が弱い点を除く と, $\mathrm{CO}_{2}$ のものとよく類似していた。 $\mathrm{m} / \mathrm{z}=30$ と $\mathrm{m} / \mathrm{z}=46$ の由来 を定量的に検討するため, Fig. 1(a)の670 Kで観察された全て の質量数の強度を $\mathrm{H}_{2} \mathrm{O}, \mathrm{CO}_{x}, \mathrm{O}_{2}$ 抢よび $\mathrm{SO}_{2}$ フラグメントと比 較したものを Table 2 に示す。表に示したように, 上記の分子 のなかで $m / z=44$ の質量数を持つものは $\mathrm{CO}_{2}$ だけである。そこ で, Spent（iii）の TPO時に観察された $m / z=44$ の質量数（強度 1749314）が全て $\mathrm{CO}_{2}$ に起因すると仮定すれば， $\mathrm{CO}_{2}$ のフラグ 
Table 2 Identification of the Products Formed during TPO of the Spent Catalyst (Spent (iii))

\begin{tabular}{|c|c|c|c|c|c|c|c|}
\hline \multirow{2}{*}{$m / z$} & \multirow{2}{*}{ Intensity ${ }^{a)}$} & \multicolumn{6}{|c|}{ Relative intensity ${ }^{\text {b) }}$} \\
\hline & & $\mathrm{CO}_{2}$ & $\mathrm{H}_{2} \mathrm{O}$ & $\mathrm{SO}_{2}$ & $\mathrm{O}_{2}$ & $\mathrm{CO}$ & $\mathrm{CH}_{3} \mathrm{CN}$ \\
\hline 12 & 138331 & & & & & 0.088 & 0.052 \\
\hline 13 & 3109 & & & & & & 0.032 \\
\hline 14 & 3868 & & & & & 0.004 & 0.112 \\
\hline 16 & 537044 & 0.056 & 0.008 & 0.052 & 0.216 & 0.044 & 0.002 \\
\hline 17 & 62814 & & 0.212 & & & & \\
\hline 18 & 243027 & & 1.000 & & & & \\
\hline 22 & 21829 & 0.012 & & & & & \\
\hline 24 & 4840 & & & 0.008 & & & 0.012 \\
\hline 25 & 1007 & & & & & & 0.024 \\
\hline 26 & 9740 & 0.002 & & & & & 0.032 \\
\hline 27 & 36187 & 0.002 & & & & & 0.016 \\
\hline 28 & 509061 & 0.064 & & & & 1.000 & 0.032 \\
\hline 29 & 7551 & 0.002 & & & & 0.008 & 0.002 \\
\hline 30 & 3047 & 0.002 & & & & & \\
\hline 32 & 1747790 & & & 0.104 & 1.000 & & \\
\hline 33 & 2300 & & & 0.002 & & & \\
\hline 34 & 8942 & & & 0.004 & & & \\
\hline 39 & 803 & & & & & & 0.192 \\
\hline 40 & 1483 & & & & & & 0.516 \\
\hline 41 & 2475 & & & & & & 1.000 \\
\hline 44 & 1749314 & 1.000 & & & & & \\
\hline 45 & 22642 & 0.008 & & & & & \\
\hline 46 & 8062 & 0.004 & & & & & \\
\hline 48 & 154355 & & & 0.492 & & & \\
\hline 49 & 1923 & & & 0.004 & & & \\
\hline 50 & 7367 & & & 0.020 & & & \\
\hline 54 & 1856 & & & & & & \\
\hline 60 & 827 & & & & & & \\
\hline 64 & 189773 & & & 1.000 & & & \\
\hline 65 & 2245 & & & 0.008 & & & \\
\hline 66 & 9331 & & & 0.048 & & & \\
\hline
\end{tabular}

a) Mass intensity observed at $670 \mathrm{~K}$ during TPO of the Spent (iii).

b) Relative mass intensity from NIST data-base.

メントとしての $\mathrm{m} / \mathrm{z}=30$ と $\mathrm{m} / \mathrm{z}=46$ の強度はそれぞれ 3500 と 7000 となる。これは実際に観察されたものの強度とよく一致 する。同様の結果はSpent（i），(ii）を用いた場合にも得られ た。言い換えれば，これらの使用済触媒のTPO時に観察され る $\mathrm{m} / \mathrm{z}=30$ と $\mathrm{m} / \mathrm{z}=46$ の強度は $\mathrm{CO}_{2}$ のフラグメントで十分に説 明できるものであり，本実験条件では $\mathrm{NO}, \mathrm{NO}_{2}$ は観察されて いないと考えられる。

一方, Table 2 を詳しく検討すると, この表に示した質量数 のなかには $\mathrm{H}_{2} \mathrm{O}, \mathrm{CO}_{x}, \mathrm{O}_{2}, \mathrm{SO}_{2}$ のフラグメントだけでは説明 できないものがいくつかあることが分かる。そのなかでも比較 的強度の強い質量数は $\mathrm{m} / \mathrm{z}=39, \mathrm{~m} / \mathrm{z}=40, \mathrm{~m} / \mathrm{z}=41$ である。こ れらのなかで最も強度の強い $m / z=41$ のプロファイルを Fig. 1(b) に示す。 $m / z=41$ のプロファイルは $m / z=44$ のものほぼ 同じ温度，すなわち $666 \mathrm{~K}$ 付近にピークトップを示すことが分 かる。 $m / z=41$ を分子イオンピークとすると, 窒素ルールおよ び $m / z=39, m / z=40, m / z=41$ の強度比から使用済触媒の TPO 時に $\mathrm{CH}_{3} \mathrm{CN}$ が生成することが示唆される（Table 2)。他の使 用済触媒を TPOに供した場合にも同様の結果が得られたこと から, 使用済触媒上には炭素種だけでなく窒素種もたい積して おり, 窒素種は $\mathrm{TPO}$ 時に $\mathrm{CH}_{3} \mathrm{CN}$ として脱離することが明らか となった。

\section{1. 2. GC/FID/FTDによる $\mathrm{CO}_{x}$ および $\mathrm{CH}_{3} \mathrm{CN}$ の定量}

使用済触媒の $\mathrm{TPO}$ 時に生成する $\mathrm{CO}_{x}$ と $\mathrm{CH}_{3} \mathrm{CN}$ を定量するた め, 本研究では次いで流出ガスの組成を高感度検出器を備えた $\mathrm{GC}$ 用いて調べた。 $\mathrm{CH}_{3} \mathrm{CN}$ 精度よく定量するため, $\mathrm{C}-\mathrm{H}$ (C-N) 結合を持つ分子に対して高い感度を有する FID (FTD) を検出器に用いた。Spent（iii）にHe処理を施してから TPOに 供した時の各検出器の応答を温度の関数として表したものを Fig. 2に示す。FIDのプロファイルに関してはTPO時に多量に 生成する $\mathrm{CO}_{x}$ の影響を調べるため，メタナイザーを用いた時の もの（Fig. 2(a)）と用いない時のもの（Fig. 2(b)）の両方を示 した。なお，それぞれの場合でFIDへのガス導入量が異なるた め，両者の強度を単純に比較することはできない。

まず，Fig. 2(a)のプロファイルはFig. 1(a)の $\mathrm{m} / \mathrm{z}=44$ のもの と非常によく似ていることが分かる。これはTPOにより生成 した多量の $\mathrm{CO}_{x}$ が $\mathrm{CH}_{4}$ として検出されているためである。一方, メタナイザーを用いないで測定した FIDのプロファイル（Fig. 2(b)）にはよりシャープなピークが現れる。メタナイザーを用 いなければ $\mathrm{CO}_{x}$ を検出できないので, このピークは $\mathrm{CO}_{x}$ ととも にC-H結合を有する分子が生成することを示唆している。さ らに，FTDのプロファイルにもほぼ同じ温度にFig. 2(b) のも のと同程度の半值幅を有するピークが現れることから，この分 
子は C-N 結合も有することが示唆される。Figs. 2(b)，(c) いず れの図に示したプロファイルのピークトップ温度も Fig. 1(b) の $m / z=41$ のもとほぼ同じであることを考慮すると, これら のプロファイルは TPO 時に生成する $\mathrm{CH}_{3} \mathrm{CN}$ に起因すると言え る。言い換えれば，メタナイザー付きの FID と FTDを備えた $\mathrm{GC}$ を使用することにより $\mathrm{TPO}$ 時に生成する $\mathrm{CO}_{x}$ と $\mathrm{CH}_{3} \mathrm{CN}$ を同 時に定量できる。

以上の結果では全て TPOの前に He処理を施したが， He処理 を施さずに TPO した場合にも同じ脱離生成物が得られた。一 方， $\mathrm{TPO}$ の前に $\mathrm{He}$ 処理を施すと $\mathrm{CO}_{2}$ と $\mathrm{CH}_{3} \mathrm{CN}$ の脱離量がいず
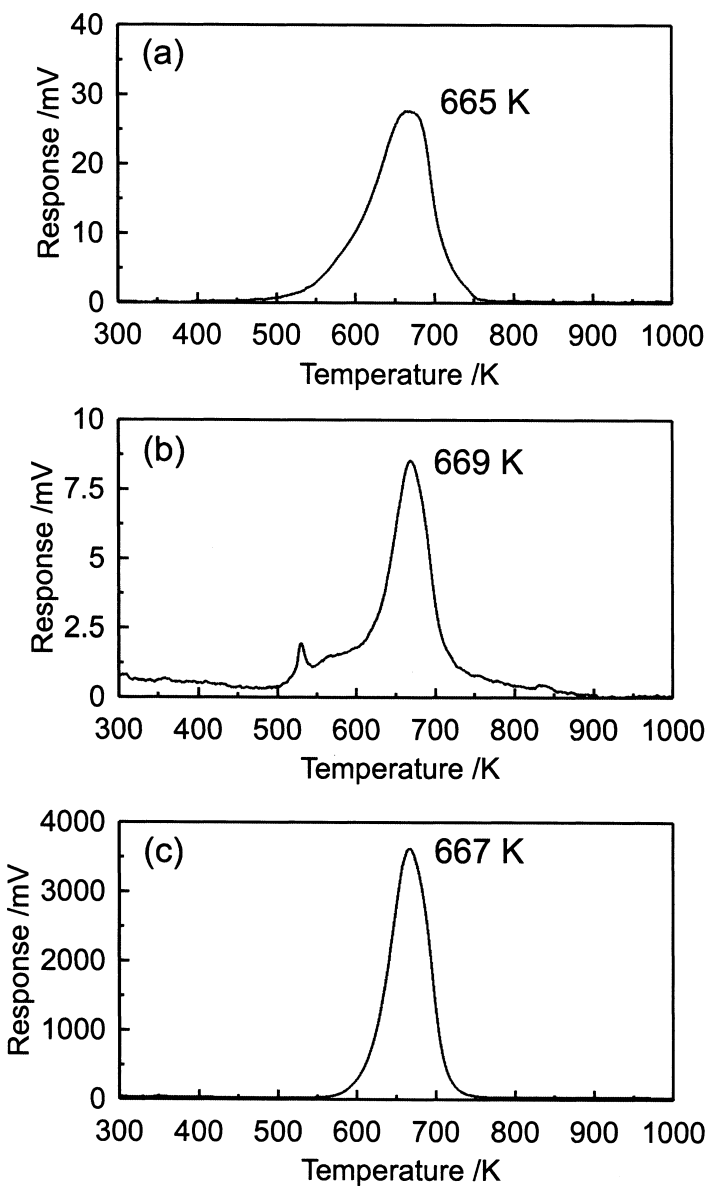

Numbers in each figure indicate the peak top temperatures.

Fig. 2 Intensity Profiles for the FID ((a) with methanizer, (b) without methanizer) and FTD ((c)) Responses during TPO of the Spent Catalyst (Spent (iii))
れも減少したことから, He処理中に使用済触媒上からたい積 炭素種や窒素種の一部が脱離すると推定された。そこで, 使用 済触媒上の炭素種と窒素種のたい積量を正確に定量するため, 以下に述べる検討では $\mathrm{He}$ 処理を施さずに試料を TPOに供し た。Table 3 にTPOプロファイルの面積強度から算出した各使 用済触媒上の炭素種および窒素種のたい積量を示す。この表か ら, たい積物の N/Cモル比は $0.02 \sim 0.04$ の範囲にあり, 超深度 脱硫反応に使用した軽油の N/Cモル比 $\left(\right.$ 約 $\left.1 \times 10^{-4}\right)$ より明ら かに高いことが分かる。このことから, 使用済触媒上に窒素が 濃縮されていることが示唆される。

既に述べたように, 重質油の水素化精製触媒に関する研究で は $\mathrm{TPO}$ 時に生成する窒素化合物は $\mathrm{NO}^{7,9)}$ (11) $\mathrm{NO}_{2}{ }^{10), 11)}$ であ り, $\mathrm{CH}_{3} \mathrm{CN}$ が生成すると報告しているものは見あたらない。 既往の研究で用いられてきた使用済触媒の履歴や組成を詳しく 検討した結果, このような相違が生じる理由として以下の可能 性を挙げることができる。すなわち, 重質油はアスファルテン 等の高分子を含む上に, それを水素化精製する際の反応条件は 軽油の超深度脱硫反応よりはるかに過酷である。そのため, 各々の反応で生成するたい積炭素質化合物の構造にも著しい違 いが生じ, 結果的にその燃焼性状に違いが生じる可能性がある。

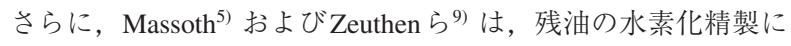
使用した触媒の TPOにおいてたい積 $\mathrm{V}$ 量の増加に伴い $\mathrm{CO}_{2}$ の

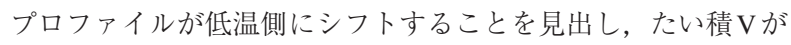
たい積炭素種の燃焼反応の触媒として働くと推定した。彼等は

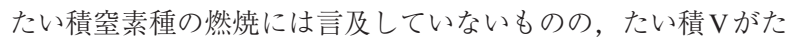
い積窒素種の燃焼も促進している可能性がある。言い換えれば, 本研究で用いた使用済触媒にはVがほとんどたい積していない ため, $\mathrm{NO}_{x}$ の代わりに $\mathrm{CH}_{3} \mathrm{CN}$ が生成した可能性もある。

\section{2. たい積炭素質化合物の燃焼性状に関する検討}

\section{2. 1. $\mathrm{CO}_{x}$ と $\mathrm{CH}_{3} \mathrm{CN}$ の生成プロファイルの解析}

使用済触媒上にどういった性状の炭素質化合物がたい積して いるのかを検討するため, 本研究では次いでメタナイザー付き の FID と FTDを用いて $\mathrm{CO}_{x}$ と $\mathrm{CH}_{3} \mathrm{CN}$ の生成プロファイルを測 定し，それぞれの生成挙動を詳細に調べた。

（1）実劣化試験に使用した触媒

Fig. 3 に実劣化試験に使用した触媒（Spent（i）（iii））を $\mathrm{TPO}$ に供した時の $\mathrm{CO}_{x}$ と $\mathrm{CH}_{3} \mathrm{CN}$ の生成プロファイルを示す。 まず, Spent（i）のプロファイルに注目すると, $\mathrm{CO}_{x}$ のプロ ファイル $($ Fig. 3(a)）には $560 \mathrm{~K}$ と $650 \mathrm{~K}$ 付近にピークが現れ ており，2本以上のピークが重畳していることが伺える。一方， $\mathrm{CH}_{3} \mathrm{CN}$ のプロファイル (Fig. 3(d)) は $660 \mathrm{~K}$ 付近にピークを示 すのみであるが, このピークは低温側に著しくテーリングして いることから，このプロファイルにも2本以上のピークが重畳

Table 3 Total Amount of Carbon and Nitrogen Deposited on the Spent Catalysts

\begin{tabular}{lccc}
\hline & Carbon [mmol/g-cat] & Nitrogen [mmol/g-cat] & N/C molar ratio \\
\hline Spent (i) & 8.2 & 0.31 & 0.04 \\
Spent (ii) & 10.6 & 0.27 & 0.03 \\
Spent (iii) & 10.7 & 0.37 & 0.03 \\
Spent (iv) & 7.9 & 0.33 & 0.04 \\
Spent (v) & 11.0 & 0.26 & 0.02 \\
Spent (vi) & 10.1 & 0.24 & 0.02 \\
\hline
\end{tabular}



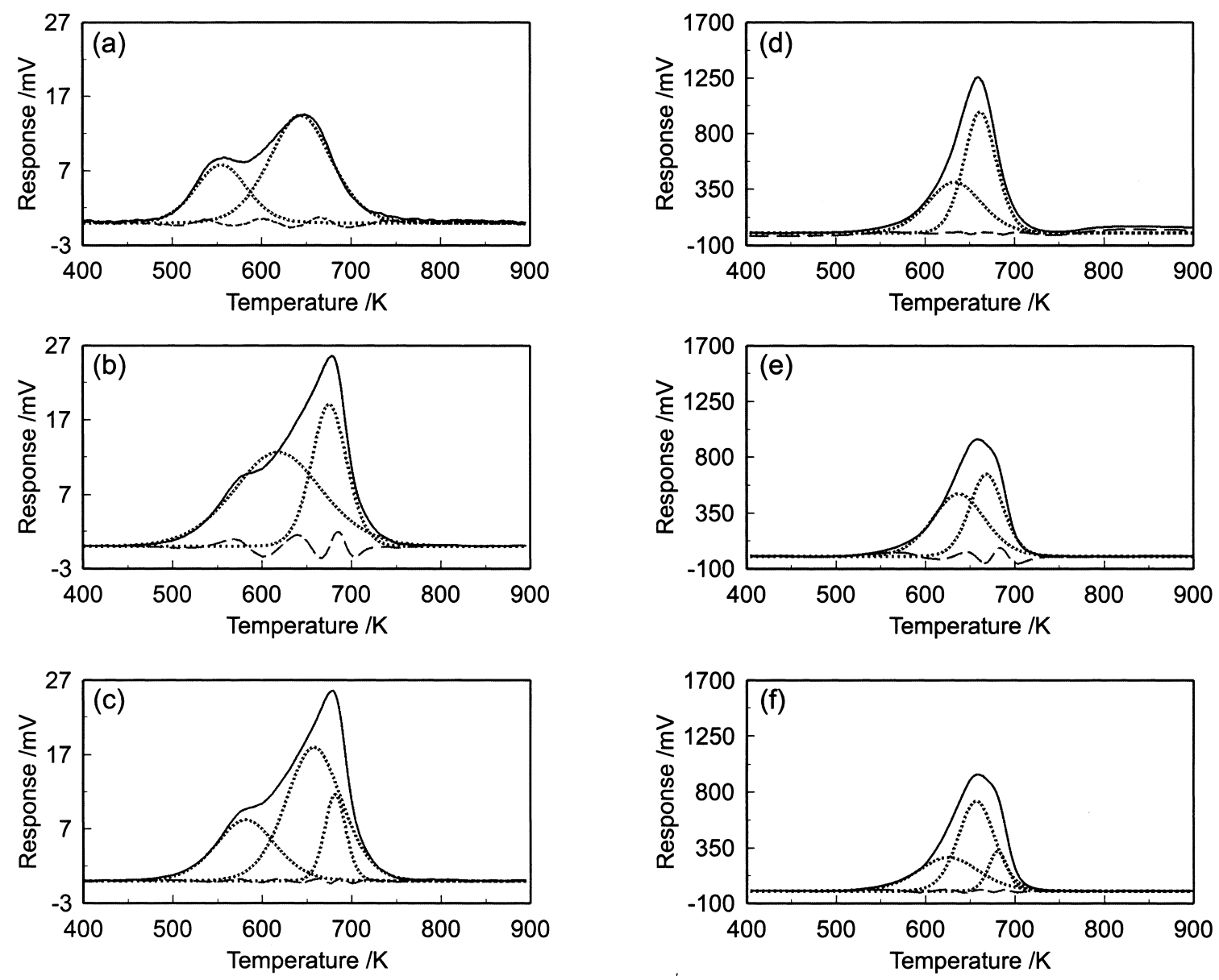

Deconvolution results for each profile are also shown in the same figure ( - observed, ------- deconvoluted and --- difference), see text.

Fig. $3 \mathrm{CO}_{x}\left((\mathrm{a})\right.$-(c)) and $\mathrm{CH}_{3} \mathrm{CN}((\mathrm{d})$-(f)) Formation Profiles during TPO of the Spent Catalysts (Spent (i) ((a), (d)) and Spent (iii) ((b), (c), (e), (f))

していると予想される。TPOにおけるピークトップ温度は燃 焼反応における活性化エネルギー $(E a)$, つまり燃焼性状と関 係する。したがって，これらのプロファイルが複数のピークで 構成されているとすれば，それは燃焼性状の異なる複数の炭素 種や窒素種が使用済触媒上にたい積していることを示唆する。 そこで，これらのプロファイルが何本のピークで構成されてい るのかを調べるためプロファイルを波形分離した。ピークには Gauss-Lorentz関数を用い，始めに2本のピークだけで波形分離 して, 実測のプロファイルとの差が大きい場合には順次ピーク の数を増やした。非線形の最小二乗法により実測のプロファイ ルとの差が最小となるように各ピークのピークトップ温度, 高 さおよび半值幅を決めた。Spent（i）のプロファイルを2本の ピークで波形分離した結果を Figs. 3(a), (d) に示す。 $\mathrm{CO}_{x}$, $\mathrm{CH}_{3} \mathrm{CN}$ いずれのプロファイルにおいても実測との差が小さく, 2本のピークで精度よく波形分離できる。

Spent（iii）を用いた時の $\mathrm{CO}_{x}$ のプロファイルを Figs. 3(b), (c) に, $\mathrm{CH}_{3} \mathrm{CN}$ のプロファイルをFigs. 3(e), (f) に示す。これ らのプロファイルの形状からSpent（i）を用いた時と同様に複 数のピークが重畳していることが予想されるため, まず2本の
ピークでプロファイルを波形分離した（Figs. 3(b)，(e)）。これ らの図にはベストフィットを示したが，この時の残差はFigs. 3(a), (d)のものより明らかに大きい。特に, $\mathrm{CO}_{x}$ のプロファイ ルでは低温側のショルダーの位置と強度に関して実測のものと 明らかな不一致が見られる。そこで, さらにこれらのプロファ イルを3本のピークで波形分離することを試みた。結果をFigs. 3(c), (f)に示す。ピークの数を 3 本に増やすと $\mathrm{CO}_{x}, \mathrm{CH}_{3} \mathrm{CN}$ ど ちらのプロファイルにもほとんど残差が現れず，非常に精度よ く波形分離できることが分かる。同様に, Spent（ii）をTPOに 供した時の $\mathrm{CO}_{x}$ と $\mathrm{CH}_{3} \mathrm{CN}$ のプロファイルも 3 本のピークで精 度よく波形分離できた。以上の結果は, Spent（i）上に燃焼性 状の異なる少なくとも2 種類の炭素種および窒素種が, また Spent（ii），(iii）上には燃焼性状の異なる少なくとも3 種類の 炭素種および窒素種がたい積していることを示唆している。

（2）加速劣化試験に使用した触媒

Fig. 4 に加速劣化試験に使用した触媒（Spent（iv）〜 (vi) ) を $\mathrm{TPO}$ に供した時の $\mathrm{CO}_{x}$ と $\mathrm{CH}_{3} \mathrm{CN}$ の生成プロファイルを示す。

まず，Spent（iv）を用いた時のプロファイル（Figs. 4(a), (d)）をFig. 3 に示したものと比較すると，いずれもSpent（i） 

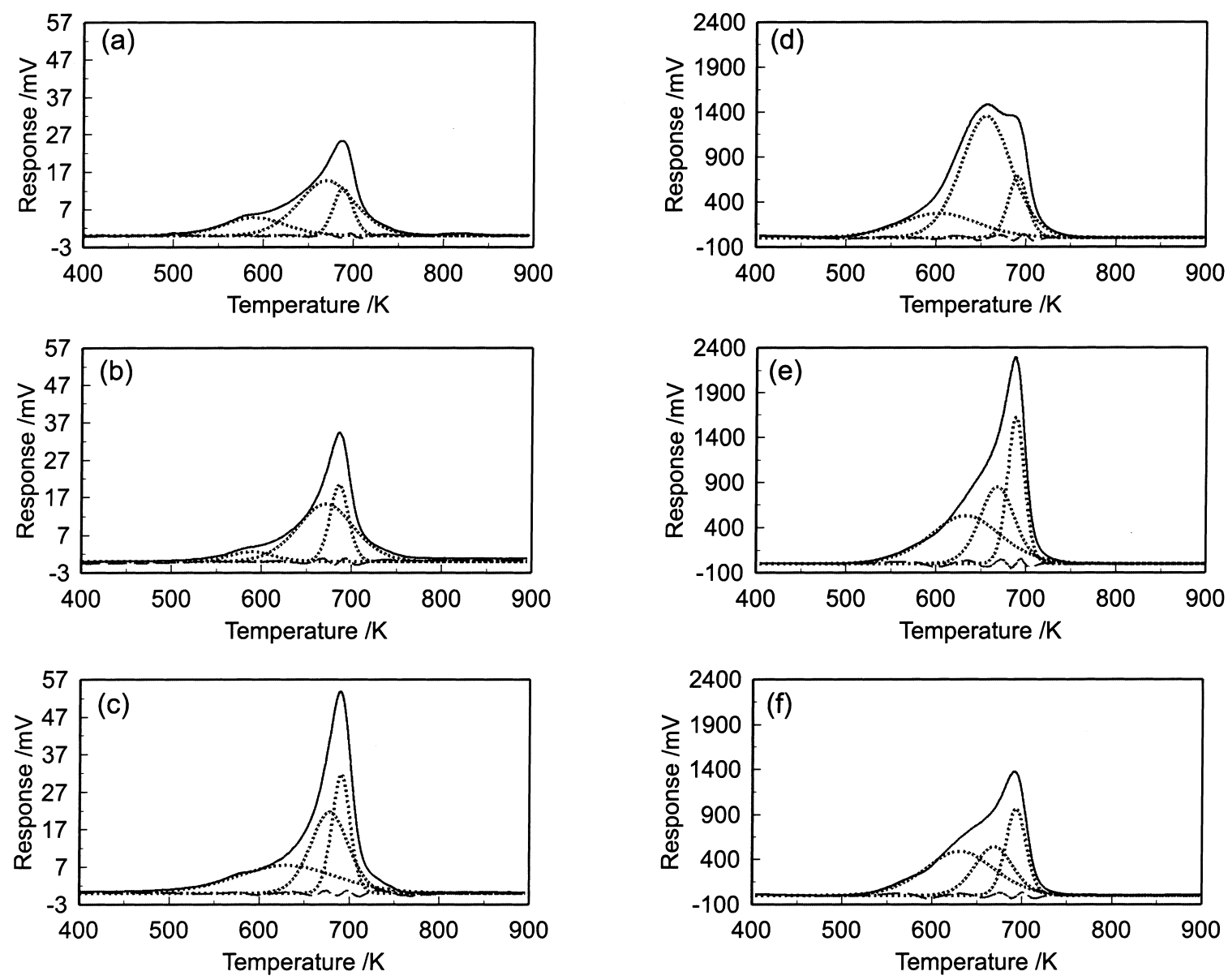

Deconvolution results of each profile are also shown ( - observed, ------- deconvoluted and - - - difference).

Fig. $4 \mathrm{CO}_{x}((\mathrm{a})-(\mathrm{c}))$ and $\mathrm{CH}_{3} \mathrm{CN}$ ((d)-(f)) Formation Profiles during TPO of the Spent Catalysts Subjected to Accelerated Deterioration Testing [Spent (iv) ((a), (d)), Spent (v) ((b), (e)) and Spent (vi) ((c), (f))]

Table 4 Peak Top Temperature for $\mathrm{CO}_{x}$ and $\mathrm{CH}_{3} \mathrm{CN}$ Formation

\begin{tabular}{lcccccccc}
\hline & \multicolumn{3}{c}{$\mathrm{CO}_{x}$ formation $[\mathrm{K}]$} & & \multicolumn{3}{c}{$\mathrm{CH}_{3} \mathrm{CN}$ formation $[\mathrm{K}]$} \\
\cline { 2 - 3 } \cline { 7 - 8 } & Peak I & Peak II & Peak III & & Peak I & Peak II & Peak III \\
\hline Spent (i) & 551 & 642 & & & 637 & 660 & \\
Spent (ii) & 589 & 666 & 680 & & 622 & 658 & 680 \\
Spent (iii) & 581 & 658 & 682 & & 626 & 657 & 681 \\
Spent (iv) & 590 & 670 & 688 & & 603 & 656 & 691 \\
Spent (v) & 589 & 671 & 686 & & 633 & 668 & 689 \\
Spent (vi) & 630 & 678 & 691 & & 631 & 669 & 693 \\
\hline
\end{tabular}

よりむしろSpent（iii）を用いた時のプロファイルに類似して いることが分かる。そこで, Spent（iv）を用いた時の $\mathrm{CO}_{x}$, $\mathrm{CH}_{3} \mathrm{CN}$ のプロファイルを3本のピークで波形分離した。結果を Figs. 4(a), (d) に示す。いずれのプロファイルにおいても実測 との差が小さく，3本のピークで精度よく波形分離できる。ま た，Spent（v)，（vi）を用いた場合にもSpent（iii）を用いた時 と形状の類似した $\mathrm{CO}_{x}$ のプロファイルが得られる。一方, $\mathrm{CH}_{3} \mathrm{CN}$ のプロファイルには違いが見られるが，この違いはFig. 4(d) に示した $700 \mathrm{~K}$ 付近のピークの相対強度が著しく増加した とすれば説明できそうである。そのため，これらのプロファイ
ルも同様に3本のピークで波形分離した（Figs. 4(b)，(e) と Figs. 4(c), (f) )。 $\mathrm{CO}_{x}$ と $\mathrm{CH}_{3} \mathrm{CN}$ どちらのプロファイルも 3 本の ピークで精度よく波形分離できていることから, 加速劣化試験 に使用した触媒上には燃焼性状の異なる少なくとも 3 種類の炭 素種掞よび窒素種がたい積していることが示唆される。

\subsection{2. たい積炭素質化合物の燃焼性状の比較}

使用済触媒上にたい積した炭素種と窒素種の燃焼性状を比較 するため, Figs. 3，4 に示した各ピークのピークトップ温度を Table 4 にまとめた。なお，この表では各ピークを低温側から 便宜的にI， II， III 表記した。 $\mathrm{CO}_{x}$ のプロファイルを構成して 

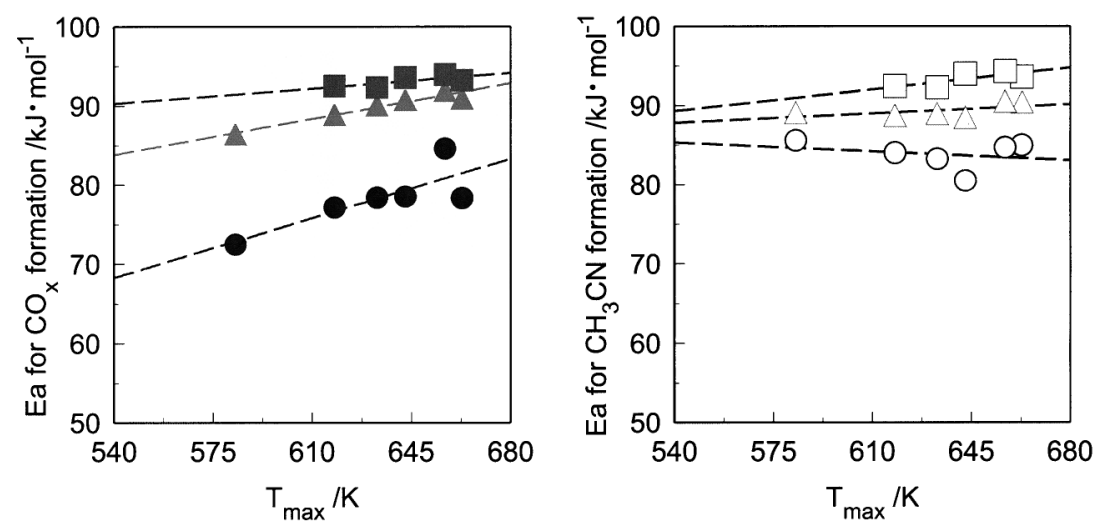

, $\bigcirc$ : peak I. $\Delta, \triangle$ : peak II. $\mathbf{\square}, \square$ : peak III.

Fig. 5 Dependence of the Activation Energies (Ea) for $\mathrm{CO}_{x}$ and $\mathrm{CH}_{3} \mathrm{CN}$ Formations on the Maximum Reaction Temperature $\left(T_{\max }\right)$

いるピークのピークトップ温度は，ピーク血に関しては触媒間 で大きな違いがないのに対して，ピーク I, IIに関しては最大 でそれぞれ約 $80 \mathrm{~K}$ と $40 \mathrm{~K}$ の差がある。つまり，ピーク I，IIの 成因となる炭素種の燃焼性状に触媒間で大きな違いがあること が分かる。一方, $\mathrm{CH}_{3} \mathrm{CN}$ のプロファイルを構成しているピー クのピークトップ温度はいずれも触媒間で大きな違いがない。

重質油の水素化精製に使用した触媒に関しては, これまでに 原料油の組成が同じであれば高い反応温度にさらされた触媒上 の炭素質化合物ほど芳香族性（ ${ }^{13} \mathrm{C}-\mathrm{NMR}$ から推定）が高いこ とが見出されている ${ }^{19)}$ 。芳香族性の高い炭素質化合物は燃焼性 が低いと予想されるが，その一方で類似の触媒の TPOではた い積炭素質化合物の燃焼に活性金属種や原料油に由来するたい 積金属種の触媒作用も関与する可能性が指摘されている5),9)。 本研究ではこれらの点を考慮した上で, ピーク I, II, III の成因 となる炭素種と窒素種の燃焼性状と反応温度との間にどのよう な関係があるのかを調べた。ここではまず，使用済触媒上の炭 素種と窒素種の燃焼が $\mathrm{O}_{2}$ 分圧に対して1次である等の仮定を おいて ${ }^{5}$, 各ピークのピークトップ温度から燃焼の際の $E a$ を計 算し, それを超深度脱硫反応時の反応温度の最高值 $\left(T_{\max }\right)$ に 対してプロットした $($ Fig. 5)。

まず，炭素種の $E a$ を見るとピーク I， II の成因となる炭素種 の $E a$ は $T_{\max }$ に対して直線的に増加するのに対して, ピーク III の成因となる炭素種の $E a$ は $T_{\max }$ によらずほぼ一定であること が分かる。 $T_{\max }$ が高い時ほどピーク II とピーク III との間で $E a$ の 差が小さくなるが, $T_{\max }=660 \mathrm{~K}$ の時でも約 $2 \mathrm{~kJ} \cdot \mathrm{mol}^{-1}$ の差があ り, いずれのピークの $E a$ も本研究で調べた $T_{\max }$ の範囲では交 差することがない。このように，それぞれのピークの成因とな る炭素種の $E a$ が $T_{\max }$ で整理できることから, それぞれのピー クの成因となる炭素種の由来は同じと推定される。言い換えれ ば， $T_{\max }=580 \mathrm{~K}$ の時を除くと使用済触媒上には少なくとも 3 種類の由来の異なる炭素質化合物がたい積していると推定され る。さらに, 軽油の超深度脱硫反応では触媒上への金属種のた い積は無視できることを考慮すると，ピーク I， II の成因とな る炭素種の $E a$ が $T_{\text {max }}$ に対して直線的に増加するのは, 触媒が 高温反応雾囲気にさらされることでたい積炭素質化合物の芳香
族性が増すためと考えられる。

一方，ピーク I， II，IIIの成因となる窒素種の $E a$ はいずれも $T_{\max }$ にほとんど依存しない。さらに, ピーク I同士, あるいは ピーク II同士で炭素種と窒素種の $E a$ を比較すると, $T_{\max }$ が低い 時には明らかに窒素種の方が $E a$ が大きのに対して, $T_{\max }=$ $660 \mathrm{~K}$ の時には両者にほとんど差がない。Eaの $T_{\text {max }}$ に対する依 存性が異なることを考慮すると, ピーク I, II の成因となる炭 素種と窒素種は炭素リッチな部分と窒素リッチな部分に分離し ていると推定される。つまり, 炭素種と窒素種の由来はそれぞ れ異なると推測される。重質油の水素化精製に使用した触媒の $\mathrm{TPO}$ では, $\mathrm{CO}_{x}$ のピークより $\mathrm{NO}_{x}$ のピークの方が高温側に現れ

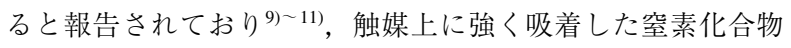
の上を炭素リッチなたい積物が覆うと提案されている。触媒上 に強く吸着した窒素化合物の構造は反応温度の影響を受けにく いと予想されること, 次節に示すようにこれらのピークの成因 となる炭素種のたい積量は窒素種のものより多いことから, 本 研究で得られた結果は重質油の水素化精製触媒に対して提案さ れていることと矛盾しない。これに対して，ピーク吕の成因と なる炭素種と窒素種の $E a$ は $T_{\max }$ によらずほぼ等しいことから, 炭素種と窒素種はほほ均一に分布しており，それぞれの由来は 同じと推測される。

\section{3. TPO から推定されるたい積炭素質化合物の生成機構}

次いで, $\mathrm{TPO}$ 時に生成する $\mathrm{CO}_{x}$ と $\mathrm{CH}_{3} \mathrm{CN}$ の生成量と波形分 離の結果から各ピークの成因となる炭素種および窒素種のたい 積量を計算し, それらが触媒の履歴にどのように依存するのか を調べた。その結果に基づいて, たい積炭素質化合物の生成機 構を検討した。

これまでに, $\mathrm{NiMo} / \mathrm{Al}_{2} \mathrm{O}_{3}$ を用いた常圧残油の HDS 反応では 通油の極初期の段階で全炭素たい積量が平衡值に達し, その後 はほとんど変化しないと報告されている23)。一方, Wiwel ら ${ }^{20)}$ は $\mathrm{NiMo} / \mathrm{Al}_{2} \mathrm{O}_{3}$ を用いて種々の重質油の水素化精製反応を行い, 反応後の触媒上の全炭素たい積量が原料油の窒素を含む多環芳 香族化合物の濃度とよく相関することを見出した。また，全窒 素たい積量に関しては反応温度が低い方がたい積量が多いと報 告されている7)。本研究ではこれらの報告を参考に, $T_{\max }$, 軽 

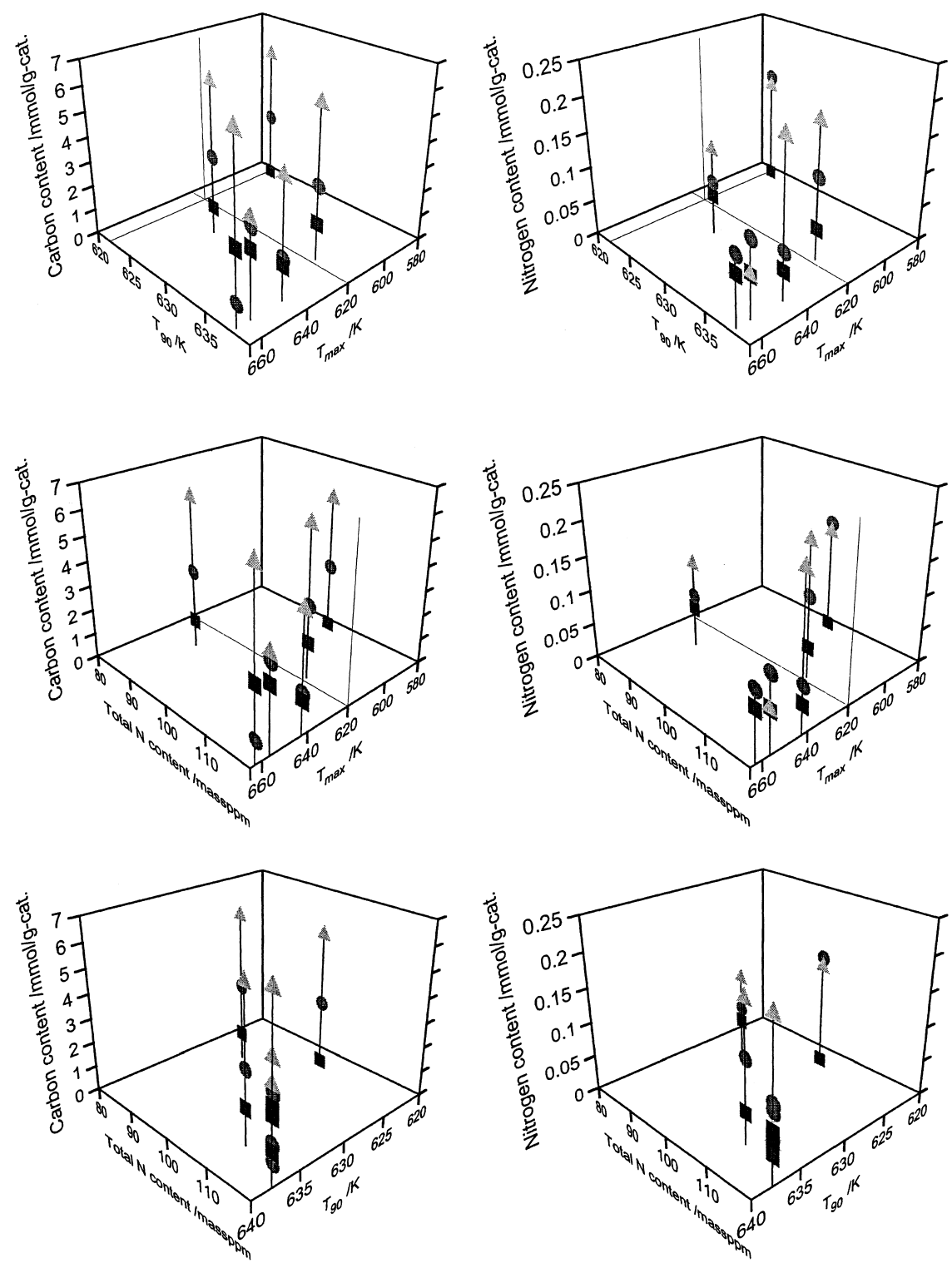

: peak I, $\mathbf{\Delta}$ : peak II,

Fig. 6 Dependence of the Carbon and Nitrogen Contents on the Spent Catalysts on the Maximum Reaction Temperature $\left(T_{\max }\right), 90 \%$ Distillation Temperature $\left(T_{90}\right)$ and Total Nitrogen Content of the Feed Gas Oil

油の全窒素濃度および重質成分の濃度の指標として $90 \%$ 留出 温度 $\left(T_{90}\right)$ に対する炭素種および窒素種のたい積量の依存性 を調べた。なお，本研究では各パラメーターを系統的に変えて いるわけではないので, 各ピークの成因となる炭素種と窒素種 のたい積量をそれぞれのパラメーターに対して3Dプロットし た（Fig. 6)。まず，炭素種のたい積量に注目すると，ピーク I, IIの成因となる炭素種のたい積量はいずれのパラメーターに対 しても明確な相関を示さないのに対して，ピーク IIIの成因とな る炭素種のたい積量は $T_{90}$ が高いほど多く， $T_{90}$ が同じ場合には $T_{\max }$ が高いほど多いことが分かる。さらに, 窒素種のたい積量 に関してもピーク IIIの成因となる窒素種のたい積量は $T_{90}$ と $T_{\text {max }}$ に対して炭素種のものとほぼ同じ依存性を示す。
たい積炭素質の前駆体物質を同定するために，原料油の組成 と全炭素たい積量との相関を調べた研究は, 重油の HDS 触媒 ${ }^{20)}$ に関して既に報告がある。一方，触媒層内ではHDS 反応だけ でなく, 水素化反応や水素化脱窒素反応も並発するため, それ らの生成物および中間体がたい積炭素質の前駆体となっている 可能性もある。この可能性を検討するためには触媒層ごとに炭 素質のたい積量と性状を調べ, それを触媒層内の原料, 生成物 および中間体の濃度プロファイルと比較する必要があるが, そ のような研究はこれまでに報告されていない。この点は本研究 でも同様であり, 今後一層の検討が必要であろう。しかし, Fig. 6に示した結果から, たい積炭素質の前駆体物質に関して ある程度の知見を得ることは可能である。すなわち， $T_{90}$ が高 


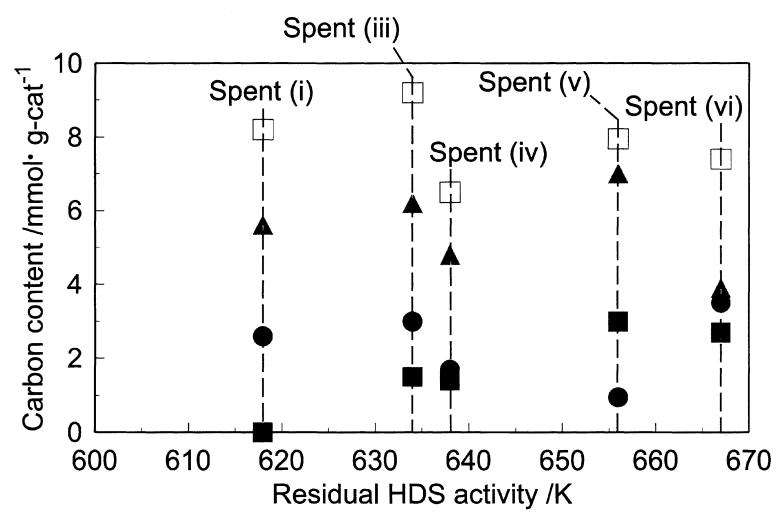

: peak I, $\boldsymbol{\Delta}$ : peak II, $\square$ : peak III, $\square$ : peak I+ peak II, see text.

Fig. 7 Relationship between the Carbon Content on the Spent Catalysts and the Residual HDS Activity

いほど軽油中の重質成分の濃度が高いと予想されることから， そのような重質成分がピーク III の成因となる炭素種と窒素種の 前駆体物質そのものでないにしても，前駆体物質の生成に何ら かの関わりを持っていると推測される。また，ピーク吕の成因 となる燃焼性の低い炭素質化合物のたい積量が $T_{\max }$ が高いほど 多いのは, 反応温度が高いほど熱分解反応や脱水素反応に起因 する吸着前駆体物質の重合 ${ }^{18)}$ の速度が大きいためと推測され る。いい換えれば, Spent（i）のTPOプロファイルにピーク III が観察されないのは原料油の $T_{90}$ がそれほど高くない上に，何 より $T_{\max }$ が著しく低いためと考えられる。一方，ピーク I， II の成因となる炭素種と窒素種の由来に関してはFig. 6から明確 な知見が得られない。前節で述べたように, 触媒上に強く吸着 した窒素化合物の上を炭素リッチなたい積物が覆うとすれば, 軽油中のより軽質なある特定の窒素化合物の吸着が引き金と なって炭素種のたい積が起こる可能性がある。

\section{4. 触媒の残存活性と炭素質化合物のたい積量}

本研究では最後に, 以上に述べたたい積炭素質化合物が触媒 の劣化とどのように関係するのかを検討するため, 触媒を抜出 す直前のHDS 活性（残存活性）を劣化の進行状態の指標とし, 各ピークの成因となる炭素種のたい積量との関係を調べた。

Fig. 7 はピーク I, II, IIIの成因となる炭素種のたい積量を各 触媒の残存活性に対してプロットしたものである。実劣化試験 に使用した触媒の残存活性は, 50 massppm 到達温度を 10 massppm到達温度に換算してプロットした。この図に示したよ うに, 本研究で用いた使用済触媒の残存活性には最大で約 50 $\mathrm{K}$ の差があり, 劣化の進行状態に触媒間で大きな開きがあるこ とが分かる。ここで残存活性が最も高いSpent（i）と残存活性 が最も低いSpent（iv）を比較すると，IおよびIIのピークの成 因となる炭素種のたい積量はほとんど変わらないか, Spent（i) の方がむしろやや多い。さらに，これらの炭素種のたい積量の 和は残存活性によらずほぼ一定とみなすことができる。これに 対して, ピーク IIIの成因となる炭素種のたい積量は残存活性が 低い（10 massppm-S を達成する温度が高い）触媒ほど多く， たい積量と残存活性との関係は単調増加関数で精度よく近似す ることができる。すなわち, 本研究で調べた範囲では実劣化試
験に使用した触媒であっても加速劣化試験に使用した触媒で あっても, 触媒の劣化の進行状態とピーク III の成因となる炭素 種のたい積量との間に単純な相関があることが見出された。こ のことから, 少なくともこの炭素質化合物のたい積が触媒の劣 化と密接に関連していると推定される。一方, ピーク I, II の 成因となるたい積炭素質が触媒の劣化にどの程度影響している のかを明らかにするためには, これらの炭素質がたい積してい ない触媒の活性を明らかにする必要がある。しかし, 予備硫化 後にわずか 2 日間原料油を流通しただけでピーク I, II の成因と なる炭素質が触媒にたい積してしまうため, 本研究ではこれら のたい積炭素質が触媒の劣化に及ぼす影響を明らかにすること はできなかった。ピークI，IIの成因となるたい積炭素質の影 響に関しては，今後一層の検討が必要である。

\section{4. 結 論}

本研究ではNiMo触媒を用いて数種の軽油の超深度脱硫反応 を異なる条件で行い, 反応後の触媒上のたい積炭素質化合物を TPO法を用いてキャラクタライズすることにより, 炭素質化 合物の成因や触媒の劣化との関連を検討した。本研究で得られ た知見をまとめると, 以下のようになる。

(1) 使用済触媒の TPOにおいて, $\mathrm{H}_{2} \mathrm{O}, \mathrm{CO}, \mathrm{CO}_{2}, \mathrm{SO}_{2}$ に加え て $\mathrm{CH}_{3} \mathrm{CN}$ が生成することが見出され, 使用済触媒上に炭素種 と窒素種がたい積していること, 窒素種は $\mathrm{TPO} に よ り ~ \mathrm{CH}_{3} \mathrm{CN}$ として脱離することが明らかとなった。

(2) $\mathrm{CO}_{x}$ および $\mathrm{CH}_{3} \mathrm{CN}$ の生成プロファイルを波形分離するこ とにより, これらのプロファイルが触媒の履歴によって2本の ピーク（どちらも $680 \mathrm{~K}$ 以下に現れる），あるいはさらに680 $690 \mathrm{~K}$ に現れるピークを加えた 3 本のピークにより構成されて いることを明らかにした。

（3）上記のピークを低温側から I, II, III とし, 各ピークの成因 となる炭素種 (窒素種) の酸化反応の活性化エネルギーを計算 した結果, ピークごとに炭素種（窒素種）の由来が異なると推 定された。

（4）ピーク I, II の成因となる炭素種と窒素種のたい積量は軽 油の全窒素濃度, $90 \%$ 留出温度 $\left(T_{90}\right)$, 反応温度の最高值 $\left(T_{\text {max }}\right)$ のいずれに対しても明確な相関を示さなかった。

（5）ピーク III の成因となる炭素種と窒素種のたい積量はどちら も $T_{90}, T_{\max }$ に対して増加傾向を示すことが見出され, ピーク III の成因となる炭素拝よび窒素種はいずれも軽油中の窒素を含む 重質成分に由来すると推定された。また，高温の反応䨌囲気下 で熱分解反応や脱水素反応による吸着種の重合が進行し, 燃焼 性の低い炭素質化合物のたい積量が増加すると推定された。

（6）ピーク IIIの成因となる炭素種のたい積量が多いほど触媒の 残存活性が低いことが見出され, 難燃焼性の炭素質化合物のた い積が超深度脱硫触媒の劣化を引き起こす一つの原因と推定さ れた。

\section{謝 辞}

本研究は, 新エネルギー・産業技術総合開発機構の委託事業 「石油精製污染物質低減等技術開発」にて行われたものである。 


\section{References}

1) NEDO Activity Report, "Research and Development of Petroleum Refining Pollutant Reduction,” Tokyo, (2001). 平成 13 年度新エネルギー・産業技術総合開発機構委託 「石油精製污染物質低減等技術開発」成果報告書.

2) NEDO Activity Report, "Research and Development of Petroleum Refining Pollutant Reduction,” Tokyo, (2002). 平成 14 年度新エネルギー・産業技術総合開発機構委託 「石油精製污染物質低減等技術開発」成果報告書.

3) Yamada, M., Shokubai, 43, (4), 276 (2001).

4) Clausen, B. S., Topsøe, H., Massoth, F. E., "CATALYSIS Science and Technology volume 11," eds. by Anderson, J. R., Boudart, M., Springer, (1996).

5) Massoth, F. E., Fuel Processing Tech., 4, 63 (1981).

6) van Doorn, J., Bosch, J. L., Bakkum, R. J., Moulijn, J. A., "Catalyst Deactivation 1987," eds by Delmon, B., Froment, G. F., Elsevier Science B. V., (1987), p. 391-402.

7) Zauthen, P., Blom, P., Muegge, B., Massoth, F. E., Appl. Catal., 78, 265 (1991).

8) van Doom, J., Barbolina, H. A. A., Moulijn, J. A., Ind. Eng. Chem. Res., 31, 101 (1992)

9) Zeuthen, P., Cooper, B. H., Clark, F. T., Arters, D., Ind. Eng. Chem. Res., 34, 755 (1995).

10) Marafi, M., Stanislaus, S., Appl. Catal. A: General, 159, 259 (1997).

11) Koide, R., Fukase, S., Al-Barood, A., Al-Dolama, K., Stanislaus, A., Absi-Halabi, M., "Catalyst Deactivation 1999," eds. by Delmon, B., Froment, G. F., Elsevier Science B. V., (1999), p. 419-422.

12) Egiebor, N. O., Gray, M. R., Gray, N. R., Appl. Catal., 55, 81
(1989).

13) Diez, F., Gates, B. C., Miller, J. T., Sajkowski, D. J., Kukes, S. G., Ind. Eng. Chem. Res., 29, 1999 (1990).

14) Hadjiloizou, G. C., Butt, J. B., Dranoff, J. S., J. Catal., 135, 27 (1992).

15) Zauthen, P., Bartholdy, J., Wievel, P., Cooper, B. H., "Catalyst Deactivation 1994," eds. by Delmon, B., Froment, G. F., Elsevier Science B. V., (1994), p. 199-206.

16) de Jong, K. P., Kuipers, H. P. C. E., van Veen, J. A. R., "Catalyst Deactivation 1991," eds. by Bartholomew, C. H., Butt, J. B., Elsevier Science B. V., (1991), p. 289-296.

17) Di'ez, F. D., Sajkowski, J., Gates, B. C., Fuel Processing Tech., 31, 43 (1992).

18) de Jong, K. P., Reinalda, D., Emeis, C. A., "Catalyst Deactivation 1994," eds. by Delmon, B., Froment, G. F., Elsevier Science B. V., (1994), p. 155-166.

19) Amemiya, M., Korai, Y., Mochida, I., J. Jpn. Petrol. Inst., 46, (2), 99 (2003).

20) Wiwel, P., Zeuthen, P., Jacobsen, A. C., "Catalyst Deactivation 1991," eds. by Bartholomew, C. H., Butt, J. B., Elsevier Science B. V., (1991), p. 257-264.

21) Terman, M., Furimsky, E., Persons, B. I., Fuel Processing Tech., 2, 45 (1979).

22) NEDO Activity Report, "Research and Development of Petroleum Refining Pollutant Reduction,” Tokyo, (2003). 平成 15 年度新エネルギー・産業技術総合開発機構委託 「石油精製污染物質低減等技術開発」成果報告書.

23) Gualda, G., Kasztelan, S., "Catalyst Deactivation 1994," eds. by Delmon, B., Froment, G. F., Elsevier Science B. V., (1994), p. 145-154. 
要旨

\title{
軽油の超深度脱硫反応に使用した NiMo触媒上のたい積炭素質化合物に関する 昇温酸化法を用いたキャラクタリゼーション
}

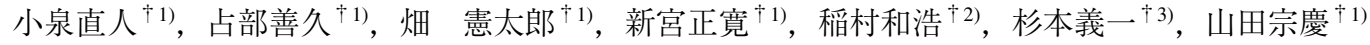 \\ †1) 東北大学大学院工学研究科応用化学専攻, 980-8579 仙台市青葉区荒巻字青葉6-6-07 \\ †2) 出光興産(株) 中央研究所 エネルギー研究室, 299-0293 千葉県袖ヶ浦市上泉 1280 \\ †3) (独) 産業技術総合研究所 エネルギー技術研究部門新燃料グループ，305-8565 茨城県つくば市東 1-1-1
}

本研究ではNiMo触媒を用いて数種の軽油の超深度脱硫反応 を種々の条件で行い，昇温酸化（TPO）法を用いて反応後の触 媒上にたい積した炭素質化合物の性状やたい積量を調べること により, 炭素質化合物の生成機構や触媒の劣化との関係を検討 した。全ての触媒のTPOに扔いて $\mathrm{H}_{2} \mathrm{O}, \mathrm{CO}, \mathrm{CO}_{2}, \mathrm{SO}_{2}$ に加え て $\mathrm{CH}_{3} \mathrm{CN}$ が生成することが見出され, 使用済触媒上に炭素種 と窒素種がたい積していること, 窒素種は $\mathrm{TPO}$ 時に $\mathrm{CH}_{3} \mathrm{CN}$ と して脱離することが明らかとなった。次いで, $\mathrm{CO}_{x}$ と $\mathrm{CH}_{3} \mathrm{CN}$ の生成プロファイルを波形分離し, これらのプロファイルが触 媒の履歴によって2本のピーク(どちらも $680 \mathrm{~K}$ 以下に現れる), あるいはさらに680〜690 Kに現れるピークを加えた3本のピー クによって構成されていることを明らかにした。つまり，使用 済触媒上には触媒の履歴によって 2 ないし 3 種類の燃焼性状の 異なる炭素種㧍よび窒素種がたい積していることが示唆され た。上記のピークを低温側から I, II, III とすると, 各ピークの
成因となる炭素種（窒素種）の燃焼反応における活性化エネル ギーから，各ピークごとに炭素種（窒素種）の由来が異なると 推定された。ピーク I, II の成因となる炭素種と窒素種のたい 積量は軽油の全窒素濃度, $90 \%$ 留出温度 $\left(T_{90}\right)$, 反応温度の最 高值 $\left(T_{\max }\right)$ のいずれに対しても明確な相関を示さないのに対 して, ピーク IIIの成因となる炭素種と窒素種のたい積量はどち らも $T_{90}, T_{\max }$ に対して増加傾向を示すことが見出された。し たがって, ピーク III の成因となる炭素種と窒素種はいずれも軽 油中の窒素を含む重質成分に由来し, 触媒が高温の反応需囲気 にさらされると熱分解反応や脱水素反応による吸着種の重合が 進行して, 燃焼性の低い炭素質化合物のたい積量が増加すると 推定された。さらに, この炭素種のたい積量が多いほど触媒の 残存活性が低いことが見出され，この炭素質化合物のたい積が 超深度脱硫触媒の劣化の一因と推定された。 